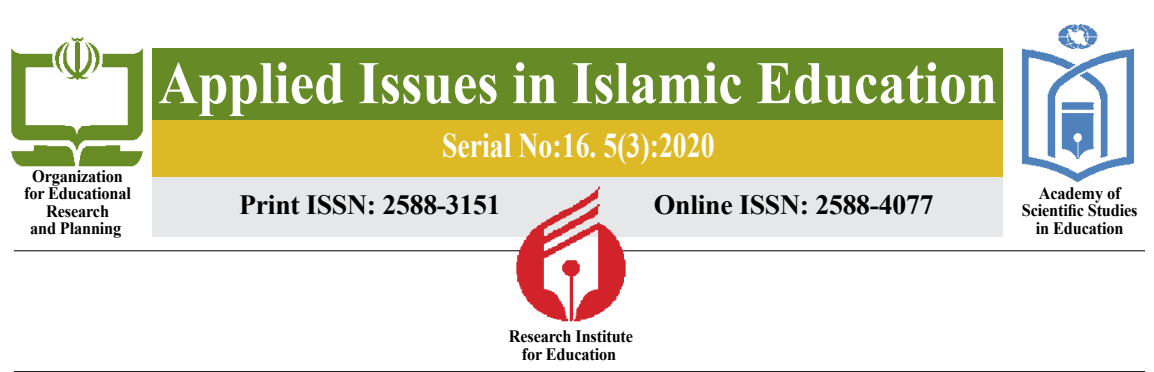

\title{
The Relationship between Religious Attitude and Academic Performance; the Mediating Role of Academic Stress in the Students of Guilan University
}

\author{
-Ebrahim Abedi ${ }^{1}$-Ali-Naqi Faqihi ${ }^{2}$-Hadi Mosadeq ${ }^{3}$-Hassan Ansari ${ }^{4}$
}

- Objectives: The purpose of this study was to investigate the relationship between religious attitude and academic performance in terms of the mediating role of academic stress among students of Guilan University.

- Method: The study population was all undergraduate students of the University of Guilan (19953) among whom the 376 subjects were selected by simple stratified random sampling method using Krejcie and Morgan table. To collect desirable data, the following questionnaires were used: Religious Attitude Questionnaire by Khodayarifard, et al (1388); Academic Performance Questionnaire by Dortaj (1382); and Academic Stress of College Students by Gadzella and Baloglu (2001). Data analysis was performed using structural equation modeling method and Amos software. The conceptual model of the research was fitted to confirmation and then the standard regression coefficients of the model were explained.

Finding: The findings showed that religious attitude has a positive direct effect of 0.32 on academic performance and also an indirect positive effect of 0.048 . Therefore, religious attitude, in addition to having a positive effect on academic performance, improves this performance in students by reducing academic stress.

- Conclusion: Therefore, the authorities are advised to make more efforts to strengthen the religious attitude of students to increase the academic performance and reduce the incidence of academic stress.

Keywords: religious attitude, academic performance, academic stress, Guilan University.

Citation: Ebrahim Abedi., \& Ali-Naqi Faqihi., \& Hadi Mosadeq., \& Hassan Ansari. (2021). The Relationship between Religious Attitude and Academic Performance; the Mediating Role of Academic Stress in the Students of Guilan University. Applied Issues in Islamic Education, 5(4): 83-108.

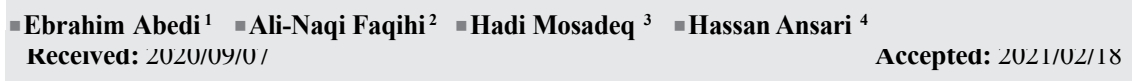

1. An MA in Educational Psychology, the Department of Educational Sciences, the Faculty of Literature and Humanities, Qom University, Qom, Iran.

E-mail: eb.abedei@gmail.com. (D) 0000-0002-2333-4420

2. Corresponding Author: An Associate Professor in Philosophy of Education, the Department of Educational Sciences, the Faculty of Literature and Humanities, Qom University, Qom, Iran. E-mail: Faghihi83@yahoo.com. (D) 0000-0003-0483-6051

3. An Assistant Professor in Educational Management, the Department of Educational Sciences, the Faculty of Literature and Humanities, Qom University, Qom, Iran.

E-mail: Hadimosadegh@gmail.com. (D) 0000- 0003-4434-545X

4. An Assistant Professor of Psychology, the Department of Psychology and Counseling, Hoda Faculty of Theology and Islamic Studies, Qom, Iran.

E-mail: hansari@rihu.ac.ir. (D) 0000- 0001-6605-1650 


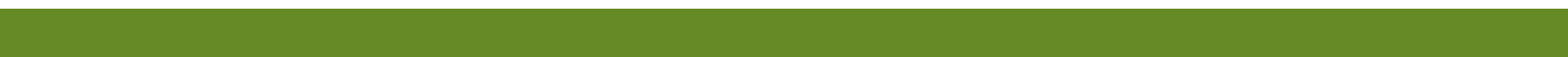



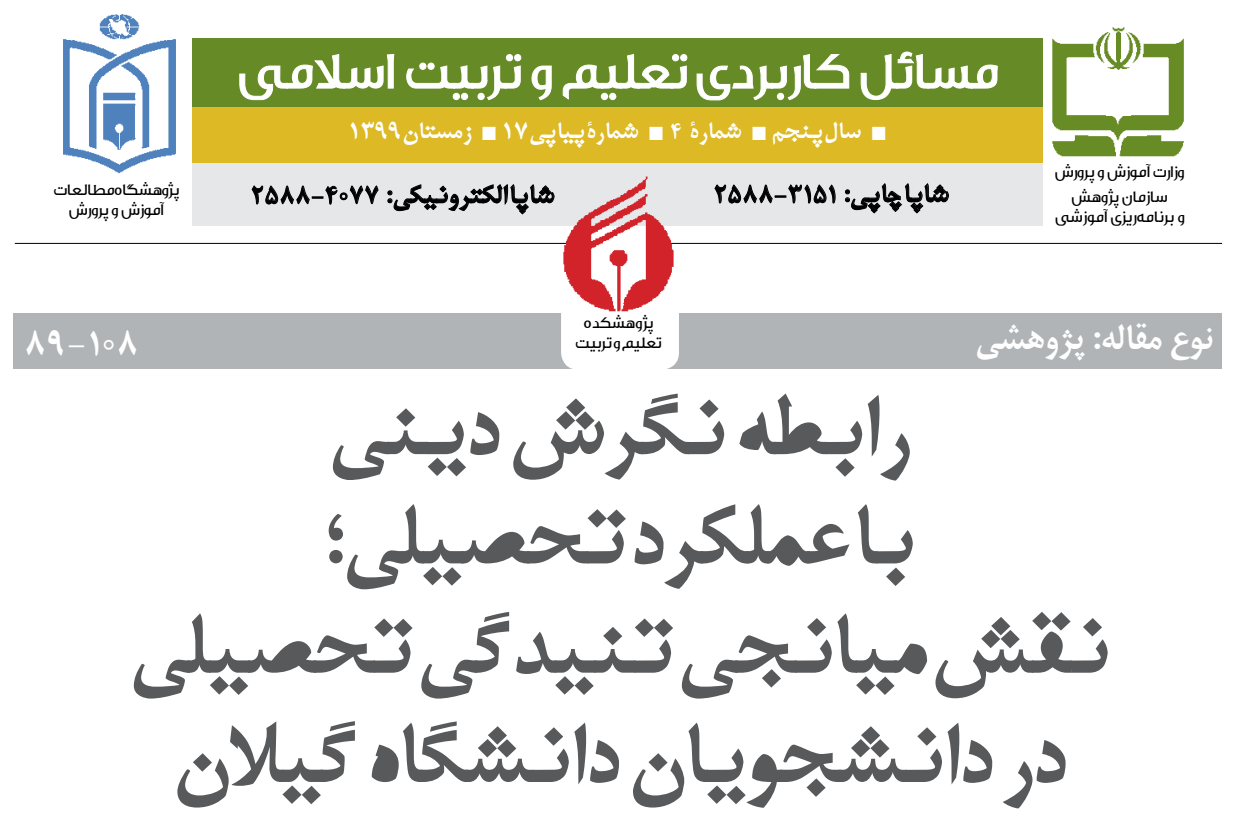

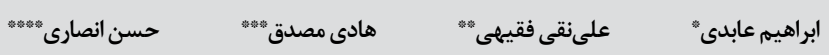

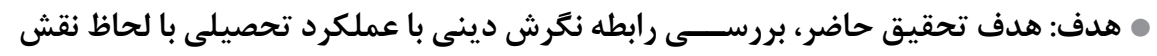

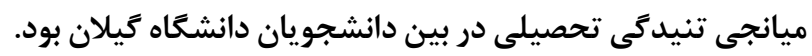

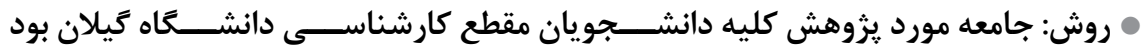

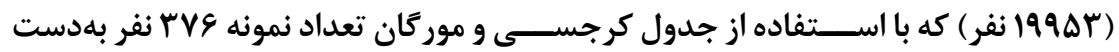

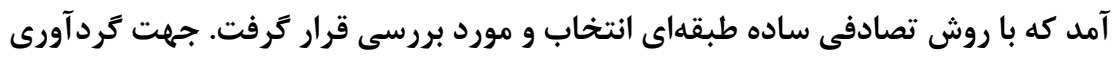

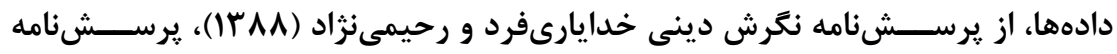

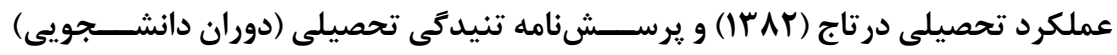
ساختئارs Gadzella \& Baloglu ساختارى و از طريق نرمافزار Amos صورت ترفت. مدل مفههومى تحقيق به برازش تأييدى

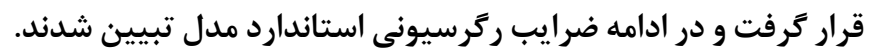

19 Email: Faghihi83@yahoo.com (iD 0000-0003-0483-6051

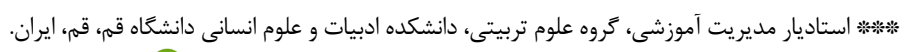
Email: Hadimosadegh@gmail.com (iD 0000-0003-4434-545X

Email: hansari@rihu.ac.ir (iD) 0000-0001-6605-1650 


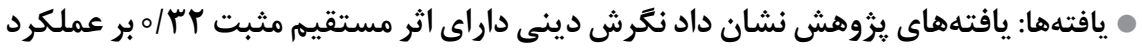

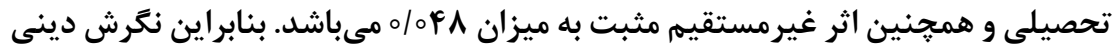

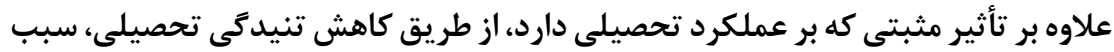

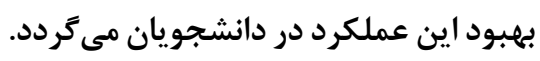

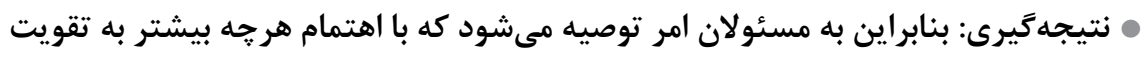

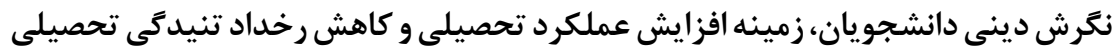

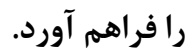

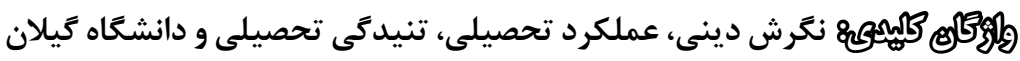

\section{مقدمه}

در شــبكه ارتباطات اجتماعى و در گردش عظيم هرخهاى تحوّل و ييشرفت و ترقى يك كشور، دانشـــويان بهعنوان متخصصين آينده نقش قابل توجهـى را ايفا مى كنند و رشـــد و بالند گى هر جامعهاى مرهون نظام آموزشى آن جامعه است (عسكرى، كهريزى

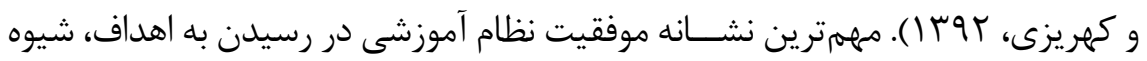
عملكرد تحصيلى فراخيران آن اســت. بهعبارتديخر، عملكرد تحصيلى بيانگر اين مطلب

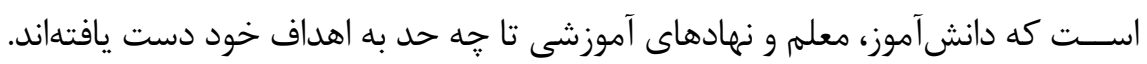

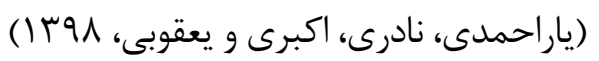

عملكرد تحصيلى شامل زيرمجموعههاى متعدد شناختى، هيجانى و انخيزشى از جمله خود كارامدى، تأثيرات هيجانى، برنامهريزى، كنترل پيامد و انخيزش است (Seif, 2016). در عصر حاضر تعليم و تربيت و بهطور كلى تحصيل بخش مهمى از زندكى افراد را تشكيل مى دهد. كيفيت و كميت تحصيل نيز بازيكر نقش مهمى در آينده افراد اســت. نزديك به يكى قرن اســت كه روانشناسان بهصورت كســترده در تلاش براى شناسايى عوامل

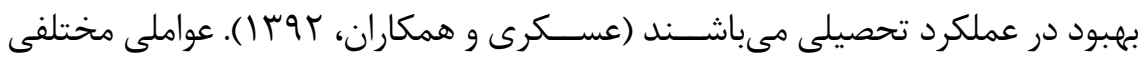
بر عملكرد تحصيلى اثر گذار هســتند؛ كه از جمله آنها مى توان به كمال گرايى تحصيلى (دشتبزركى، هوץ ()، خود كارامدى تحصيلى (موســوىنزاد، مهدىزاده و صالحآبادى،

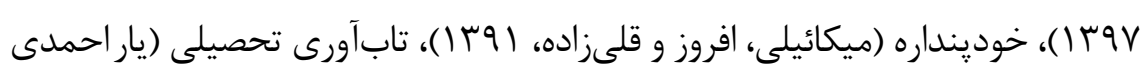




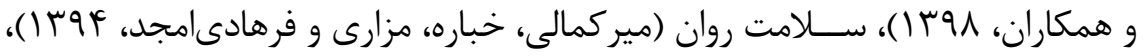
كيفيت و سبك زندگى (سعيدى و فرحبخش، هوس (1)، ساز گارى تحصيلى (باقرى جاروى،

توحيدى و تجربه كار، \૧ | ()، هيجانهاى تحصيلى (سليمانى شبيلو، واحدى و نعمتى،

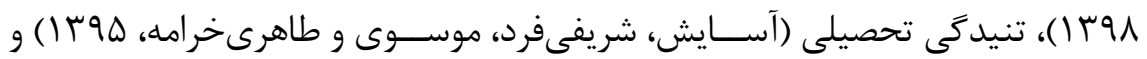
نغرش دينى (عسگرى و صفرزاده، rوץ|) اشاره كرد. همان طور كه اشاره شد، متغير تنيدگى تحصيلى و نخرش دينى نيز بهعنوان متغير هاى مؤثر بر عملكرد تحصيلى بيان شــدهاند، لكن تاكنون رابطه همزمان اين سه متغير مورد بررسى قرار نخرفته و از اينرو، يروهش به دنبال كشف روابط معادلاتى بين نخرش دينى با عملكرد تحصيلى با لحاظ نقش ميانجى تنيدگى تحصيلى بوده است. ○نيدَّى تحصيلى: درحالى كه حضور در دانشــاه براى عده كثيرى از دانشجويان تجارب مثبتى به همراه دارد، براى برخى ديخر مطالب تحصيلى از قبيل آزمونها، مقالات، ارائه مطالب و غيره با تجربه تنيد طيف وسيعى از تجارب تحصيلى تنيدگىزا را براى دانشجويان به همراه مى آورد؛ بنابراين،

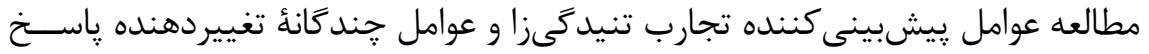
به تجارب تنيد گىزا از اهميت جشــمخيرى برخوردار اســت (Kariv \& Heiman, 2005). تنيدگى تحصيلى 'به احســاس نياز فزاينده به دانــش و بهطور همزمان، ادراك فرد مبنى بر نداشتن زمان كافى دستيابى به آن دانش اشاره مى كند. در خصوص مؤلفههاى

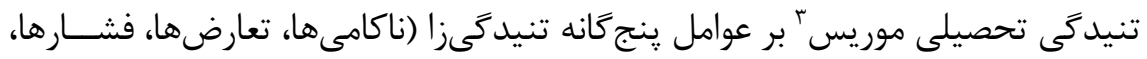
تغييرات و تنيدگى خود تحميل شده) و واكنشهاى جهار گانه به اين عوامل (فيزيولوزيكى،

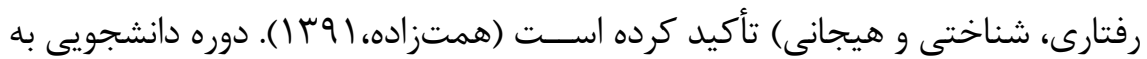
دليل شرايط خاص از جمله دورى از خانواده، حجم زياد دروس، رقابتهاى فشرده و غيره، زمينهساز مشكلات فردى و اجتماعى زيادى براى دانشجويان است. (دشتبزرتى، هوس ا ) افســردَى، اضطراب، مشكلات رفتارى و تحريكـيذيرى از معدود مشكلاتى است كه در فراكيران داراى تنيدگى تحصيلى بالا گزارش شــده اســت (Deb, Strodl \& Sun, 2015). يروهش هاى مختلفى در خصوص ارتباط بين اســترسها و تنيدگى تحصيلى با عملكرد 
تحصيلى انجام شـــه و رابطـــه بين تنيدگى و عملكرد تحصيلى (آســـايش و همكاران،

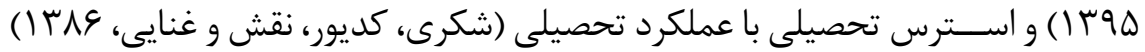

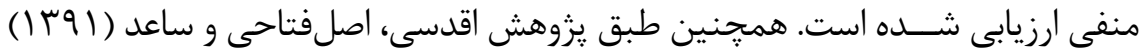
ايمنسازى در مقابل استرس اثر مثبت بر عملكرد تحصيلى دارد. نكًرش دينـى': عبارت اســت از اعتقادات منســجم و يكيارجه توحيدى كه خداوند را محـــور امور مىداند و ارزشها، آداب، رســوم و رفتارهاى انســان با يكديخر، طبيعت و خويشـــن را تنظيم مى كند (عليجانى، اورنتى، نورالدينــى و مصدرى، لوس ( ). برخى متكلمان غربى از جمله دورانت در تعريف دين كفتهاند: دين نظام الهى اســت كه براى

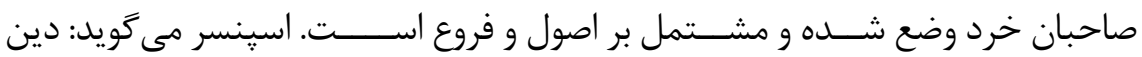
وسيلهاى براى توضيح راز جهان و تبيين يديدههاى دينى بر اساس حالت درونى و تحوّل

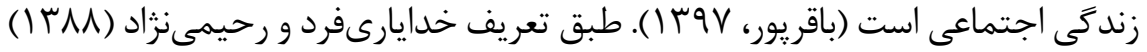
نخرش دينى عبارت است از شناخت و باور به يرورد كار يكتا، انبياء، آخرت و احكام الهى، داشـــن عواطف نسبت به خدا، اوليا و بندكان خدا و التزام و عمل به وظايف دينى براى

$$
\text { تقرب به خداوند. }
$$

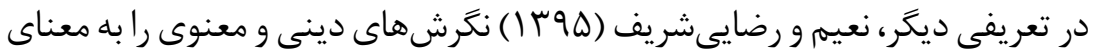

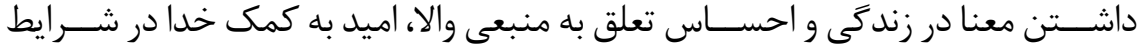
مشـــكلزاى زندگى و بهرهمندى از حمايتهاى اجتماعى و معنوى دانســــاند كه افراد

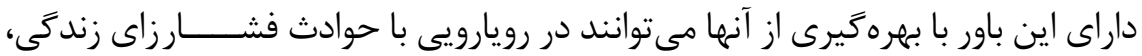
آسيب كمترى متحمل شوند (باقريور، Vو I ).

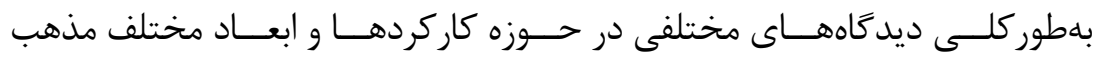
و نخرش دينى توســط انديشــمندان ارائه شده اســت. در مدل كاركردى به نقش دين

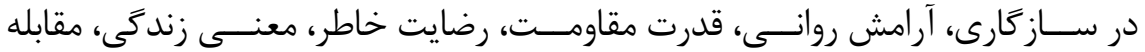

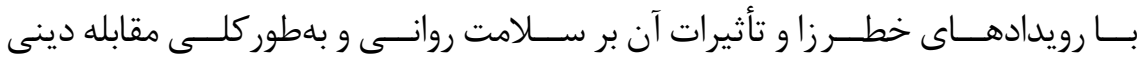

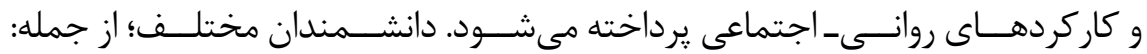
Misiak, Ellison, Pargament, Patrick, Valeriet \& Laurie, Levin, Merton

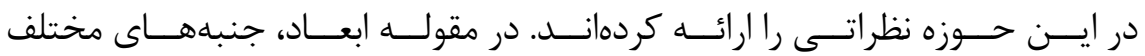




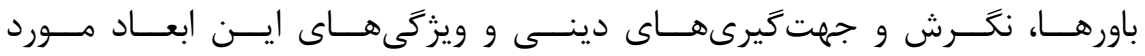

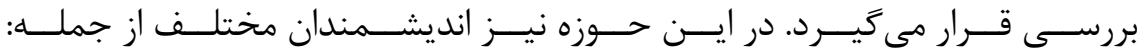

Allport , Erich Fromm , Gorsuch , Korniejezuk , Ganzevoort , Smart , Von Hugel

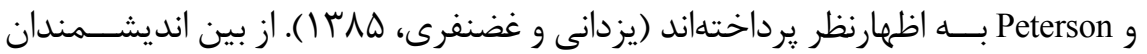
مسلمان نيز مى توان به نظريه تركيبى استاد مطهرى اشاره كرد كه در آن، بعد از تشريح ابعاد دين، كاركردهاى ســــَّانه دين را بهجت و انبساط (شامل خوشبينى، روشندلى، اميدوارى، آرامش خاطـــر و لذت معنوى)، بهبود روابط اجتماعـى و كاهش ناراحتىها

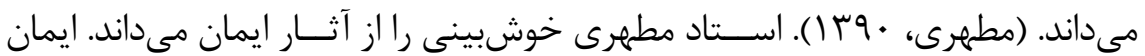
دينى از آن جهت آفرينش را هدفدار و هدف را خير، تكامل و ســعادت معرفى مى كند، طبعاً ديد انسان را نسبت به نظام كلى هستى خوشبينانه ميىسازد. فرد باليمان قوانين،

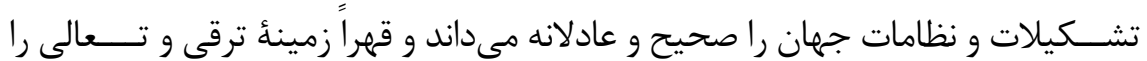
بـــــاى خودش و همه افــــراد ديخر فراهم مىبيند. اين انديشه او را به غيرت مى آورد و

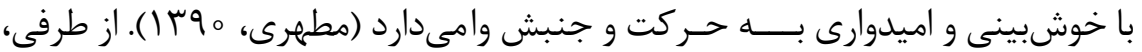
اضطراب از شك و ترديد بهوجود مى آيد. آنجه انسان را به اضطراب و نگرانى مى كشاند و تكليف خويش را درباره او روشن نمىبيند، جهان است. ايمان مذهبى از آنجا كه نسبت به جهان اعتماد و اطمينان مىبخشد، دلمره و نكرانى نسبت به رفتار جهان را در برابر انسان زايل مىسازد و آرامش خاطر به همراه مى آورد (مطهرى، هوس آ ).

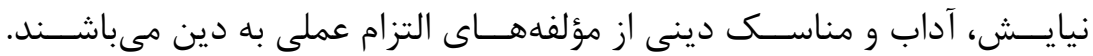

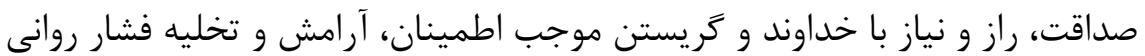

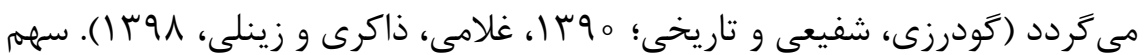
بزرگى از نمره تنيدگى تحصيلى، مربوط به واكنشهاى شناختى، رفتارى، هيجانى و فيزيولوزيكى است كه در ياسخ به استرسهاى تحصيل ايجاد مىشوند و تهديد كننده ســلامت روان و عملكرد افراد مى باشند. اضطراب، افسردكى، يرخاشگرى، خود كشى، گرايش به مصرف ســيعار و مواد مخدر و... بخشـى از اين واكنشها هستند. در اين راســتا رابطهُ بين تابآورى با دين مثبت ارزيابى شده است (جمشيدى، عربمقدم و 
يِيشبينى كننده مناسبى براى عملكرد تحصيلى هستند. يزوهش عباسى، خادمى و نقش

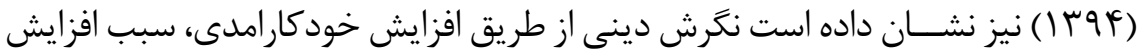
انخيزش ييشرفت تحصيلى مى گردد؛ مقولههايى كه از مؤلفههاى اصلى عملكرد تحصيلى هستند. افراد با نخرش مذهبى بالا، مؤلفههاى بيشترى از سبك زندگى اسلامى را اختيار

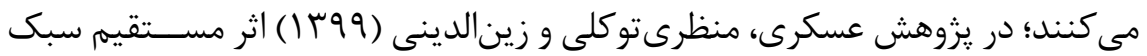

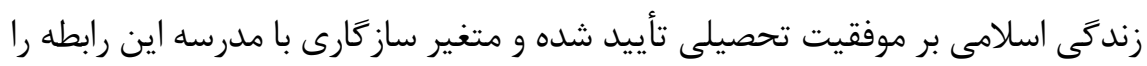
واسطة كرى مى كند. نَرش دينى همجنين مىتواند اثر كاهشى بر تنيدگى تحصيلى داشته باشد. يزوهش مُ

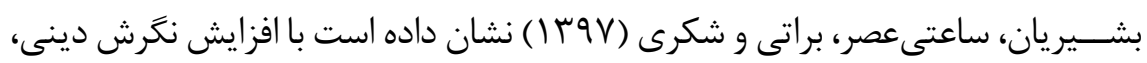

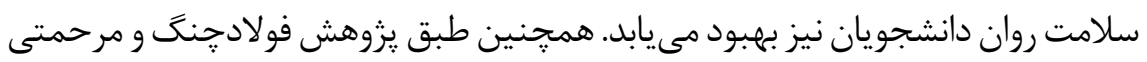
(9 (1) آموزش مهارتهاى زندىى (از منظر اسلام و روانشناسى) موجب بهبود وضعيت بهزيستى روانشناختى در دانشجويان مى گردد. كسانى كه از اعتقادات مذهبى قوىترى برخوردارند، نســبت به مقابله با عوامل فشـــارزاى روانى، شخصى و عملكرد تحصيلى از نيروى بيشــترى برخوردارند و در رويارويى با اين عوامل فشـــارزا كمتر دجار افسردكى و ديخر بيمارىها مىشوند (عســكرى و همكاران، بوس إ: V • (). مطابق با يافته والريت

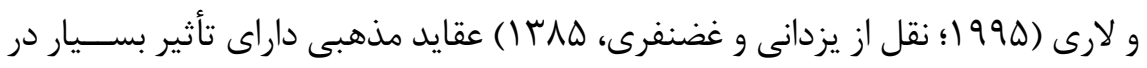
سيســتم اجتماعى و ييجيده زند غذايى و ورزش مىباشــــ. باورهاى مذهبى به بهبود ســامت، كيفيت زندكى و افزايش عزتنفس منجر مى گردد (نزادنادرى، ديوسالار، محمودى و درهكردى، موسا ا: 11).

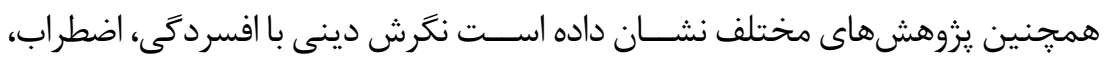
يرخاشخرى خو خودبيمار انگًارى رابطهمنفى دارد.(Trevino,Pargament,Kenneth\&Cotton,2007)

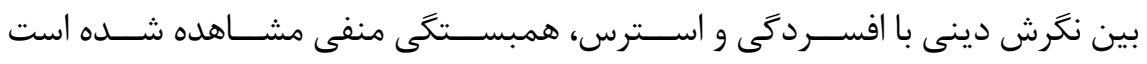

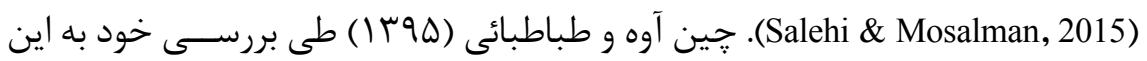
نتيجه رسيدند افرادى كه اعتقاد درونى به خدا و باورهاى مذهبى دارند، از اين اعتقادات

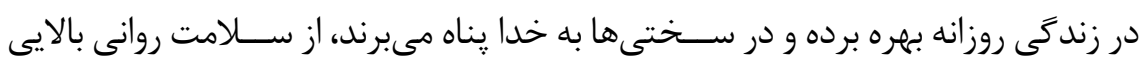
برخوردارند و كمتر درگير افكار مخرّب خودكشــى مىشــــند. اين افراد بروز فشار روان

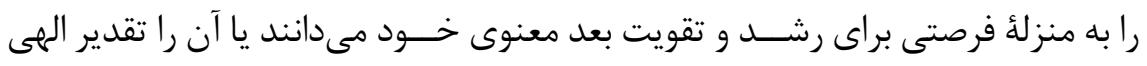


تعبير و تفســير مى كنند. طبق يافتههاى (Mochon, Norton \& Ariely, 2011) و غبارى

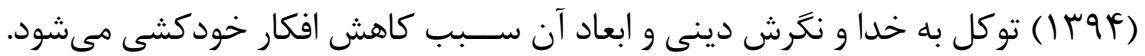
نتايج يزوهش بهامين، داورى فرد، ملكشاهى و آبى (هوس ا) نيز نشان داده است افراد با بادي گرايش مذهبى بالا، گرايش كمترى به مصرف سيگار دارند. همجنين اصغرى، كردميرزا و احمدى (rq (I) به اين نتيجه رسيدند كه بين گرايش دينى و سوءمصرف مواد رابطه

$$
\text { منفى معنادار وجود دارد. }
$$

با توجه به اينكه در هر جامعهاى، دانشجويان قشر سرنوشتساز و متخصصين آينده جامعه هســتند و سلامت روانى و رضايت از زندگى اجتماعى، تحصيلى و خانوادگى آنان حائز اهميت اسـت و همجنين با توجه به اينكه درصد بالايى از جمعيت كشــور شامل جوانان و دانشجويان است، بررسى عوامل مرتبط با تنيدگى هايى كه هنگام تحصيل با آن روبارو مىشوند و عواملى كه مى توانند سبب بهبود عملكرد تحصيلى آنها باشند، اهميت بالايى دارد. بنا بر آنجه مرور شـــ، دين عامل افزايش ســلامت و كاهش استرسها و اضطرابها

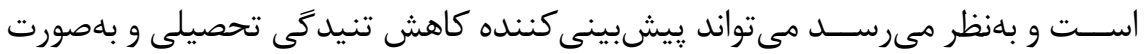
مســتقيهم يا از طريق كاهش متغير ميانجى تنيدگى تحصيلى، ييشبينى كنـنده عملكرد تحصيلى بهتر باشــد. در يزوهش هاى كذشته تأثيرات مذهب و مقابله مذهبى از ديد انديشمندان مختلف اعم از مسلمان و غيرمسلمان بررسى شده كه هر كدام به جنبههايى

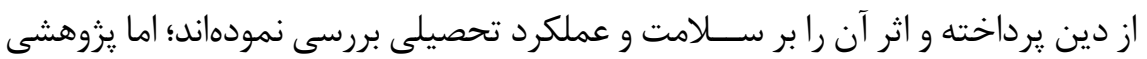

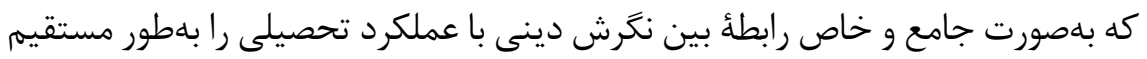

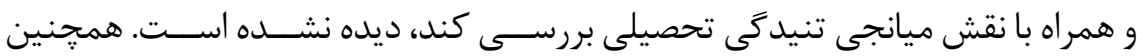
جنبه ديخرى از تازگى در اين يزوهش سنجش متغير نخرش دينى بر مبناى انديشههاى اسلامى، متشكل از سه زيرمؤلفه باورها، عواطف و التزام عملى مىباشد. بنابر اين يزوهش

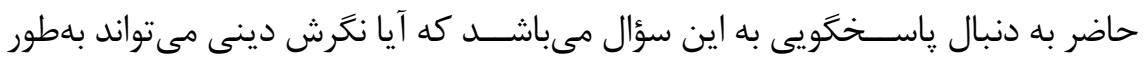

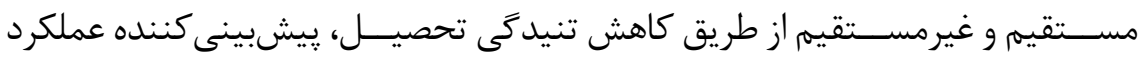

\section{تحصيلى بهتر باشد؟} در نهايت بر مبنى ادبيات تحقيق بيان شده، مىتوان مدل مفهومى زير را براى تحقيق 


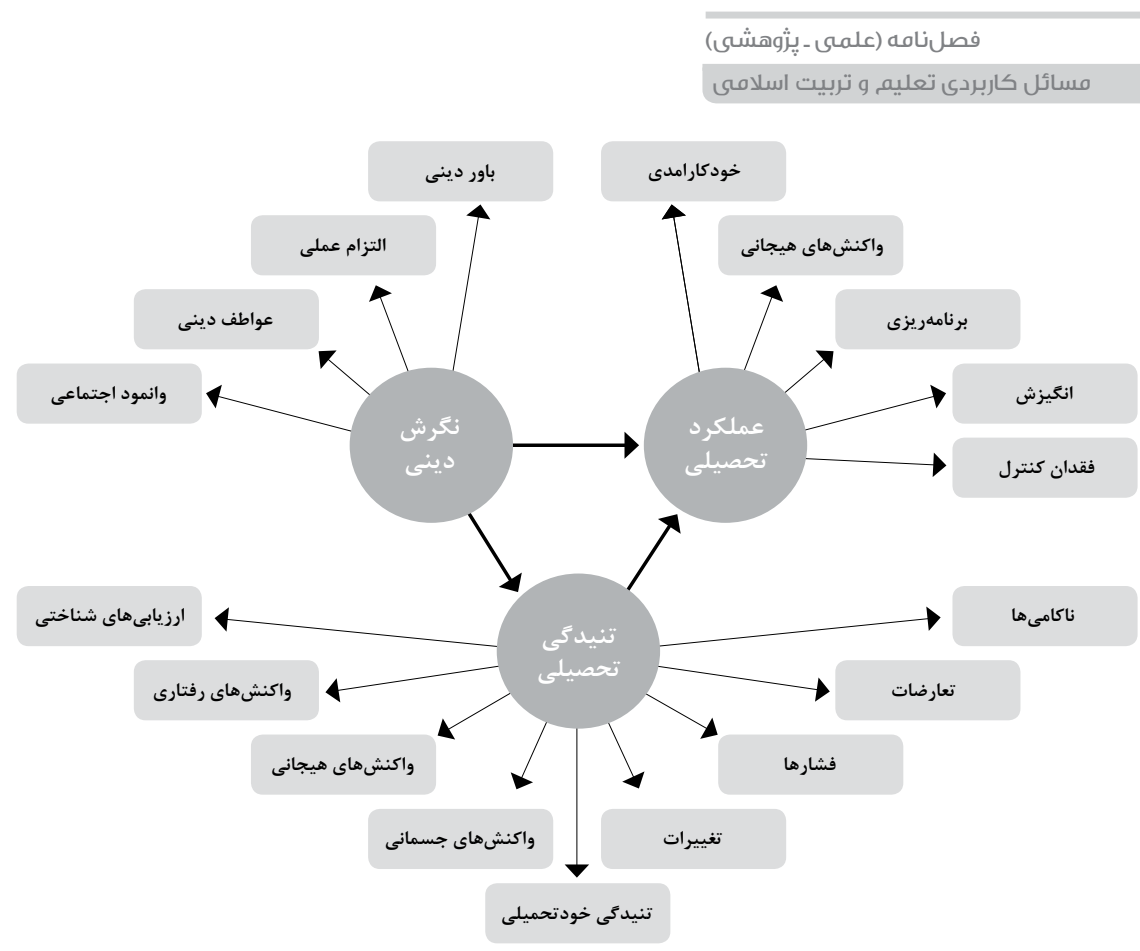

نمودار ا. مدل مفهومى ييشنهادى جهت بررسى

\section{روش يزوهش}

يزوهش حاضر يك مطالعه توصيفى مقطعى از نوع همبســتخى است كه رابطؤ بين

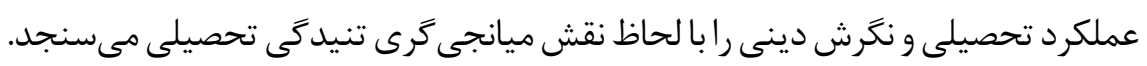

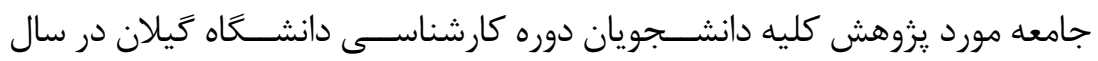

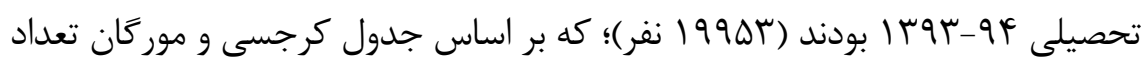

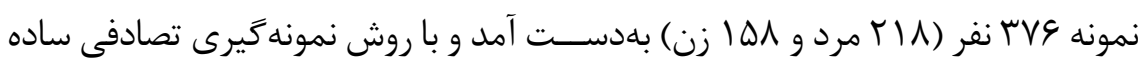

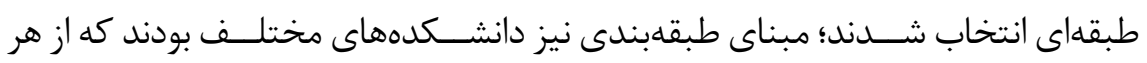

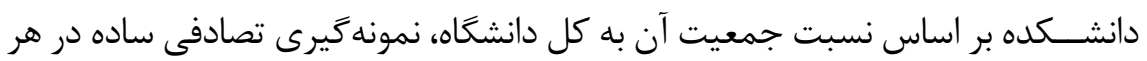
دانشكده بهعمل آمد.

\section{ابزار تحقيق}

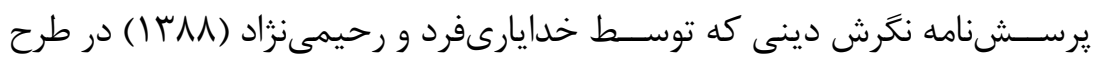

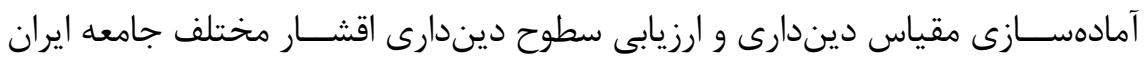

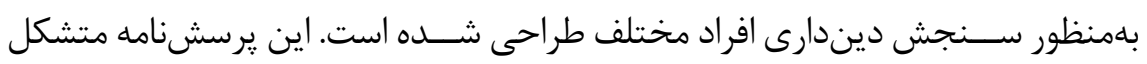


از ه F Fويه ســـنش ديندارى در سه مؤلفه باور دينى، عواطف دينى و التزام و عمل به وظايف دينى و نيز \& عَويهاندازهَيرى وانمود اجتماعى و تلاش براى ارائه تصوير مطلوب

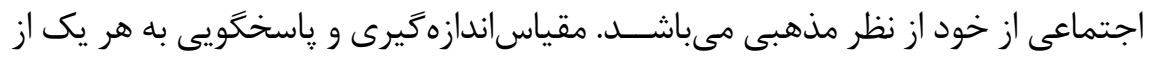
عبارات مؤلفهها طيف ليكرت ينج درجهاى اســت كه براى گويهها درجات هميشه، اكثر

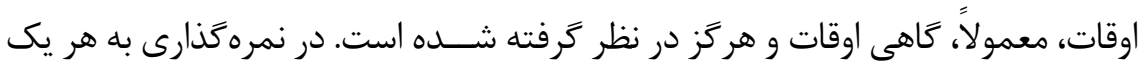
از درجات مقياس از 1 تا ه برحســب كم به زياد تعلق مى گيرد. نمره هر مؤلفه بر اساس اس امتياز هر عبارت مؤلفه با هم جمع مىشود. نمره كل ديندارى نيز از جمع نمره هر مؤلفه

$$
\text { با هم بهدست مى آيد. }
$$

روايى اين آزمون از طريق روايى محتوايى (صورى و منطقى)، روايى ملاكى همزمان

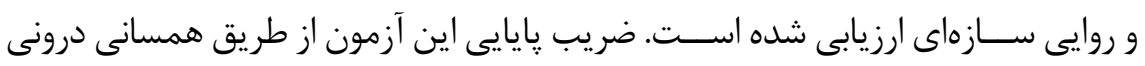

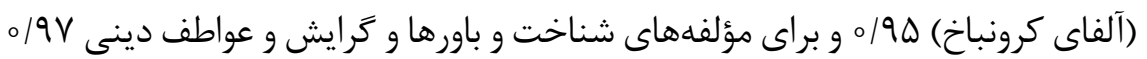
و براى مؤلفه التزام و عمل به وظايف دينى 9 9/ه بهدســت آمده؛ كه نشاندهنده يايايى

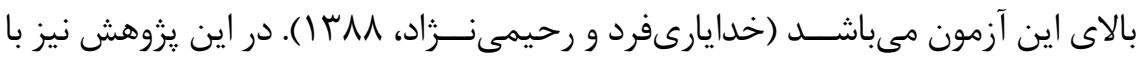
محاسبه همسانى درونى با آلفاى كرونباخ، يايايى باور دينى، التزام عملى و عواطف دينى

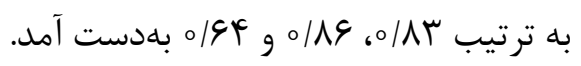

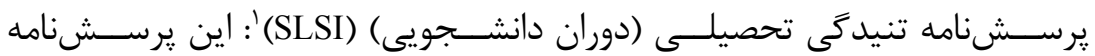

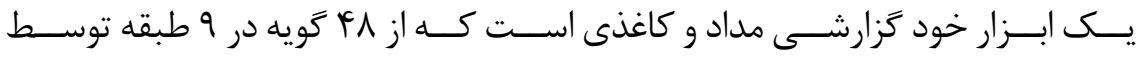
طراحى شــده است. اين ابزار بر مدل نظرى توصيف شده (Gadzella \& Baloglu, 2001) به وسيله موريس (9a0) (9adzella \& Baloglu, 2001 مبتنى است. مدل مذبور ه نوع (طبقه) تنشـــر (ناكامىها، تعارضات، فشارها، تغييرات و تنيدگى خود تحميلى)

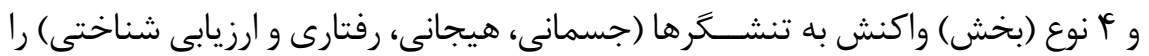
ارزيابى مى كند. در هر زيرمقياس براى بهدســت آوردن يك نمره كل، گويهها با يكديگر جمع مى شوند. نمرات بالاتر به ترتيب نشاندهنده تنيدگى تحصيلى بيشتر و واكنش هاى بيشتر تنشخر ها است. 
تعارضها، فشــارها، تغييرها، تنيدگى خود تحميلى، واكنشهاى جســمانى، هيجانى،

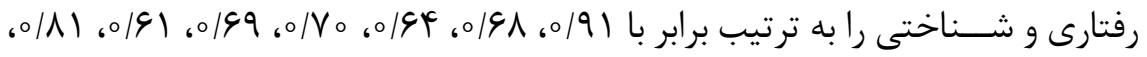
o/VV

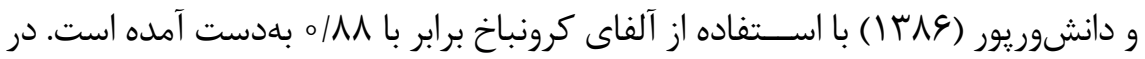
يزوهش حاضر نيز بهوسيله محاسبه همسانى درونى با آلفاى كرونباخ، يايايى مؤلفههاى ناكامىها، تعارضها، فشارها، تغييرات، تنيدگى خود تحميلى، واكنشهاى فيزيولوزيك،

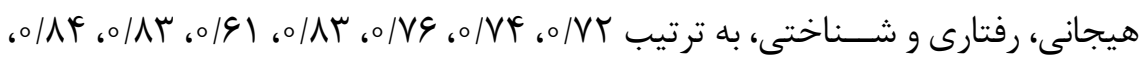

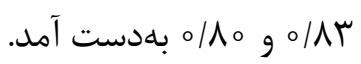

يرســشنامه عملكرد تحصيلى درتاج: اين آزمون برداشتى از يزوهشهاى فام و تيلور

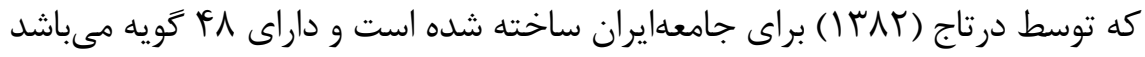

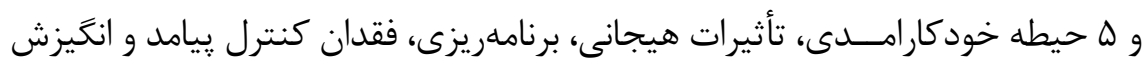

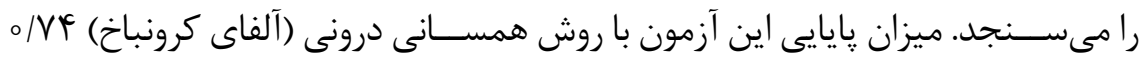
بهدست آمد. روايى اين آزمون از طريق روايى محتوا و روايى سازه ارزيابى گرديد (درتاج،

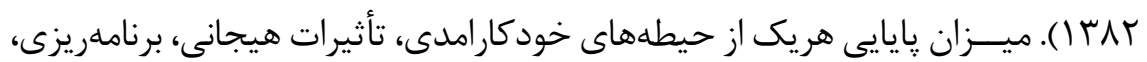

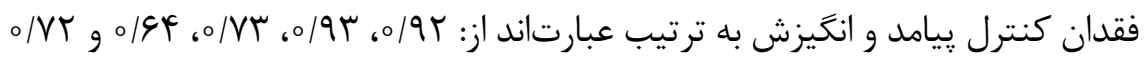

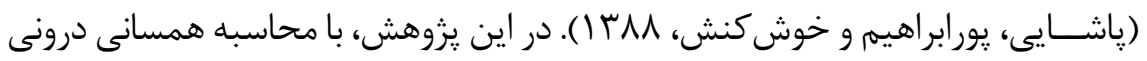

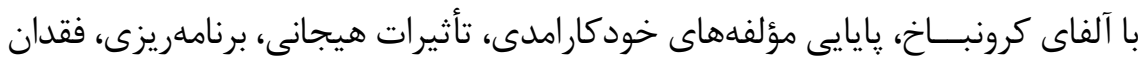

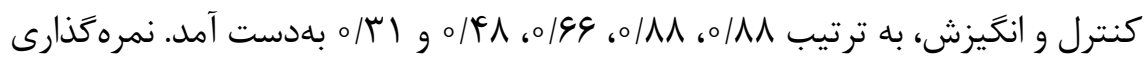
اين آزمون از طريق مقياس ليكرت صورت مى گيرد. براى هر يك از زويهها يك طيف ينج

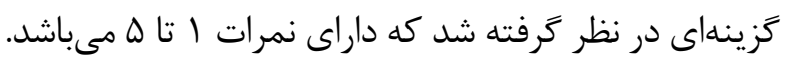
بـــراى تجزيه و تحليل دادهها در اين يزوهش از روش مدل معادلات ســاختارى و از نرمافزار Amos استفاده شد. در ابتدا مدل مفهومى تحقيق به برازش تأييدى قرار گرفت و در ادامه ضرايب ركرسيونى استاندارد مدل تبيين شدند.

\section{يافتهها}

همانطور كه بيان شــد مسئله يزوهش اين است كه آيا نخرش دينى مى تواند بهطور مســتقيم و غيرمســتقيمم از طريق كاهش تنيدكى تحصيلى، ييشبينى كنـنده عملكرد 
بر اساس مدل مفهومى تحقيق كه در نمودار ل ، به آن اشاره شده است، نگرش دينى

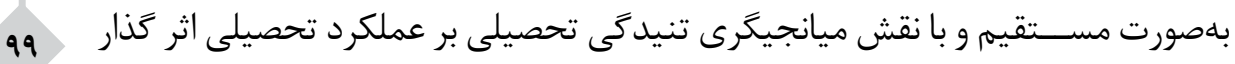
مىباشد. براى سنجش اين مدل بر اساس دادههاى ميدانى، لازم است در گام اول، مدل

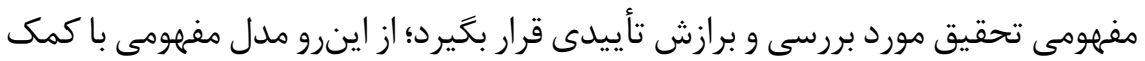
نرم افزار Amos تحليل گرديدكه نتايج برازش مدل در جدول ا. بيان شده است.

جدول ا. مقدار شاخص هاى برازش تحليل مدل ساختارى

\begin{tabular}{|c|c|c|c|c|}
\hline وضعيت & 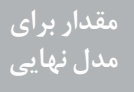 & حد قابل قبول & نام شاخص & شاخصها \\
\hline مطلوب & 1/9 & $\mathrm{X}^{r} / \mathrm{df} \leq \circ \circ . r$ & $\begin{array}{c}\text { نسبت مجذور خى به درجه آزادى } \\
\left.\text { ( } \chi^{2} / \mathrm{df}\right)\end{array}$ & \multirow{3}{*}{ بازمص مطلقى } \\
\hline مطلوب & 01000 & $P>0.0 \Delta$ & $\begin{array}{l}\text { حد معنادارى } \\
\text { (Sig) }\end{array}$ & \\
\hline مطلوب & 0101 & $\mathrm{RMR}<0 . \circ \Delta$ & $\begin{array}{c}\text { ريشه ميانَّين مجذور باقيمانده } \\
\text { (RMR) }\end{array}$ & \\
\hline مطلوب & ०/94 & $१ / \mathrm{GFI} \geq 。$ & $\begin{array}{c}\text { شاخص نكويى برازش } \\
\text { (GFI) }\end{array}$ & \multirow{4}{*}{ 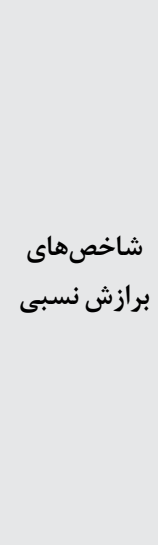 } \\
\hline مطلوب & $0 / 94$ & $q / \mathrm{AGFI} \geq 。$ & شاخص تعديلشدهى نكويى برازش & \\
\hline مطلوب & ०/99 & $q / \mathrm{IFI} \geq \circ$ & $\begin{array}{c}\text { شاخص برازش فزاينده } \\
\text { (IFI) }\end{array}$ & \\
\hline مطلوب & $\circ / 90$ & $q / \mathrm{CFI} \geq 。$ & $\begin{array}{c}\text { شاخص برازندگى تطبيقى } \\
\text { (CFI) }\end{array}$ & \\
\hline مطلوب & 01049 & RMSEA $\leq . . \diamond \wedge$ & $\begin{array}{c}\text { جذر برآورد واريانس خطاى تقريب } \\
\text { (RMSEA) }\end{array}$ & برازش مقتصد \\
\hline
\end{tabular}


منابع مورد اســتنـاد در خصوص شاخصهاى برازش مدل هاى معادلات ساختارى از جمله قاسمى (rqY (1) شاخصهاى بيان شده در ستون سوم جدول I را مورد اشاره قرار دادهاند كه حد قابل قبول هر كدام از شاخصها را نيز بيان كردهاند و در جدول مورد اشاره قرار گرفتـه اســت. نتايج جدول ا، نشـــان مى دهد كه تمام شاخصهاى برازش در سطح قابلقبولى هســـند؛ بنابراين دادههاى اين :يزوهش در تحليل مدل معادلات ساختارى، برازش مدل مفهومى يزوهش را نشــان داد. در ادامه ضرايب رگرسيونى استاندارد مدل تبيين شده در جدول r تا جدول ه ارائه شده است. ابتدا در جدول r، به بررسى ضرايب رگرسيونى بين شاخصهاى اصلى يرداخته شده

\section{جدول r. ضرايب رترسيونى بين شاخصهاى اصلى}

\begin{tabular}{|c|c|c|c|}
\hline تبيين شاريانس & بهـح معنادارى آمده (sig) & وزن ركاندسيونى & فاكتوروها \\
\hline$\circ / 10$ & $\circ / 001$ & o/Tr & رابطه نگرش دينى و عملكرد تحصيلى \\
\hline o/०rt & $\circ / 009$ & $-0 / 11$ & رابطه نخرش دينى و تنيدگى تحصيلى \\
\hline$\circ / 0 V T$ & $\circ / 000$ & $-\circ / T V$ & رابطه تنيدگى تحصيلى و عملكرد تحصيلى \\
\hline
\end{tabular}

همانطور كه در جدول r، بيان شده است، بين سه شاخص مورد بررسى رابطههاى معنادار، ولى ضعيفى برقرار است؛ كه بين شاخص لانگرش دينى" و "اعملكرد تحصيلى"

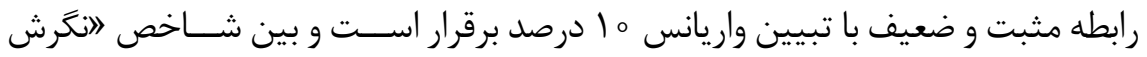
دينــى" و لاتنيدگى تحصيلى " رابطه معنادار ضعيف و منفى بـــا تبيين واريانس تقريباً "اصدم برقرار اســت و بين 》تنيدگى تحصيلى" و اعملكـــرد تحصيلى" رابطه منفى و

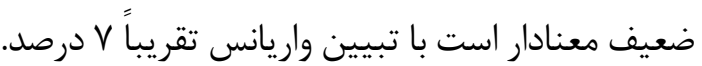
يافتههاى تحقيقات نشان داد كه شاخص نخرش دينى داراى اثر مستقيمم مثبت بr/ه

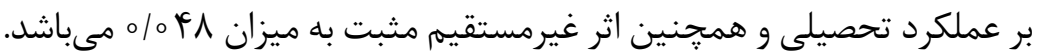
يافتههاى جدول r، به نحو بهترى در نمودار r. ترسيمى شده است. 


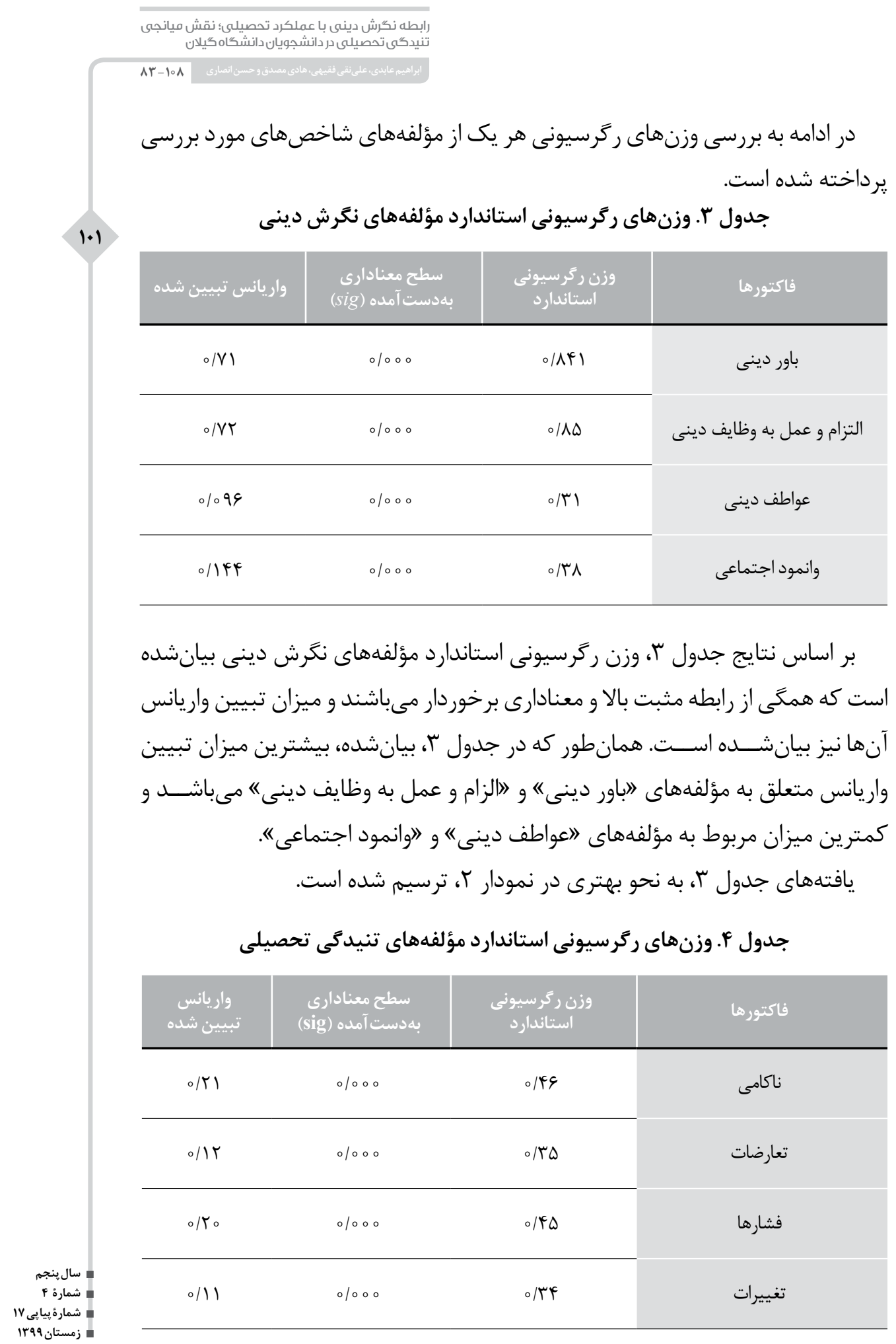


جدول F) (ادامه)

\begin{tabular}{|c|c|c|c|}
\hline تبيين شاريانس & $\begin{array}{l}\text { سطح معنادارَم آمده (sig) } \\
\text { (sig) }\end{array}$ & وزن رتانرسيونى & فاكتوروها \\
\hline 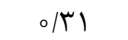 & $\circ / 000$ & $\circ / \Delta \varphi$ & خود تحميلى \\
\hline $0 / 9 Y$ & $\circ / 000$ & $\circ / V q$ & واكنش هاى جسمانى \\
\hline$\circ / \varepsilon F$ & $\circ / 000$ & $\circ / \Lambda \circ$ & ى هيجانى \\
\hline $0 / 9 Y$ & $\circ / 000$ & $\circ / V q$ & واكنش هاى رفتارى \\
\hline$\circ / 11$ & $\circ / 000$ & سז/ס & ارزيابي شناختى \\
\hline
\end{tabular}

بر اســاس نتايج جدول أ، وزن رگرسيونى اســتاندارد مؤلفههاى تنيدگى تحصيلى بيانشده است كه همگى از رابطه مثبت بالا و معنادارى برخوردار مىباشند و ميزان تبيين واريانس آنها نيز بيانشــده است. همانطور كه در جدول أل، بيانشده، بيشترين ميزان تبيين واريانس متعلق به مؤلفههاى واكنش هاى "هيجانى"، "رفتارى" و "جســمانى"

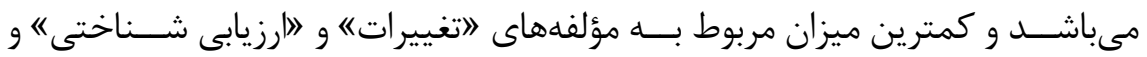
1تعارضات 《 مىباشد. يافتههاى جدول f أ به نحو بهترى در نمودار r، ترسيم شده است. جدول ه. وزنهاى ركرسيونى استاندارد مؤلفههاى عملكرد تحصيلى

\begin{tabular}{|c|c|c|c|}
\hline واريانس تبيين & 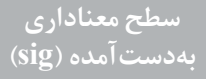 & وزن ركترسيونى & فاكتورها \\
\hline$\circ / \Delta \varphi$ & $\circ / 000$ & $\circ / V \Delta$ & خودكار آمدرى \\
\hline$\circ / \circ \Delta$ & $\circ / 000$ & o/Tr & تأثيرات هيجانى \\
\hline M/T & $\circ / 000$ & $\circ / \uparrow \wedge$ & برنامهريزى \\
\hline$\circ / \circ \mathrm{V}$ & $\circ / 000$ & $\circ / T \Lambda$ & انخيزش \\
\hline
\end{tabular}


بر اســاس نتايج جدول ه، وزن رگرسيونى اســتاندارد مؤلفههاى عملكرد تحصيلى بيانشده است كه بهاســتثناء مؤلفه لفقدان كنترل/ همكَى از رابطه مثبت و معنادارى

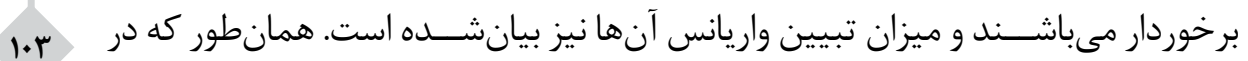
جدول بيانشــده، بيشترين ميزان تبيين واريانس متعلق به مؤلفههاى لاخودكارآمدى"

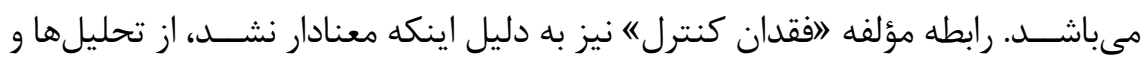
جدول حذف شد. يافتههاى جدول ه، به نحو بهترى در نمودار r، ترسيم شده است.

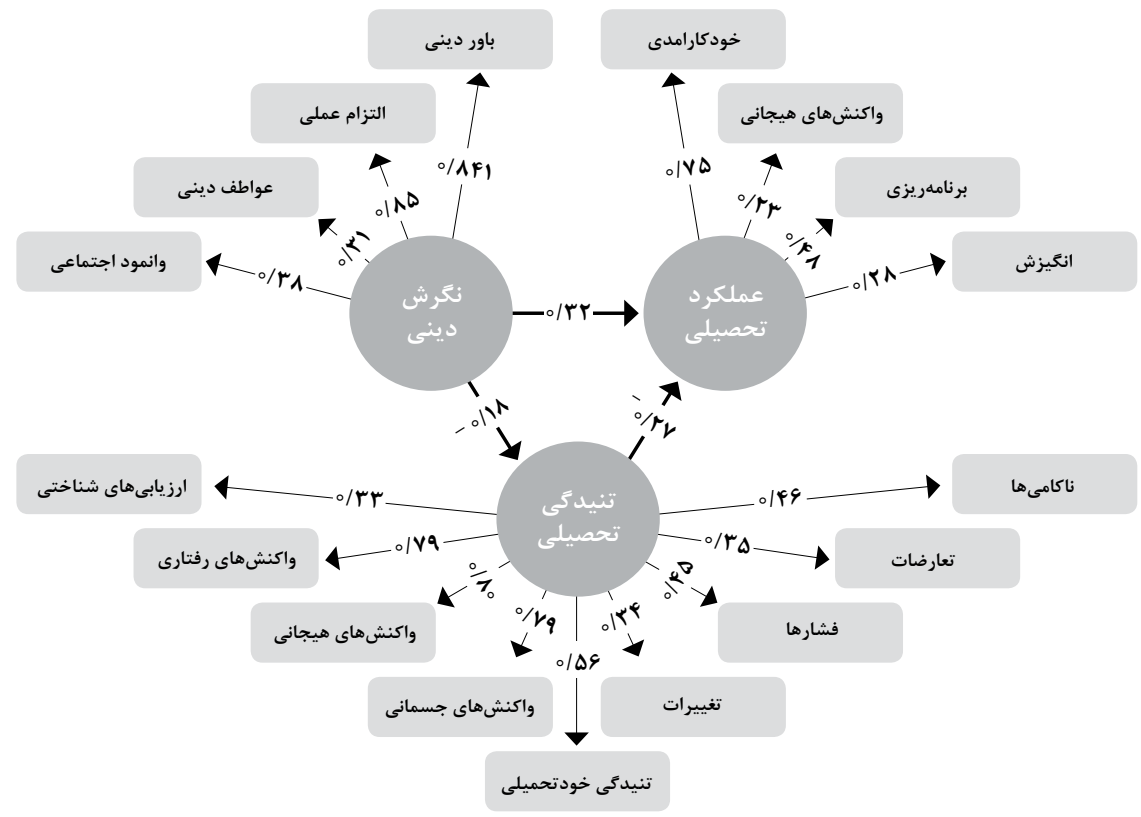
نمودار r. مدل برازش

\section{بحث و نتيجحه}

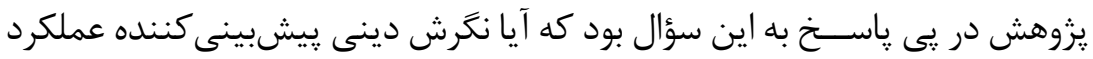
تحصيلى بهتر مىباشــــ طبق يافته يزوهش، نخرش دينى داراى اثر مستقيمم مثبت بر عملكرد تحصيلى است و افرادى كه نخرش دينى بالاترى دارند، از عملكرد تحصيلى بهـتىى

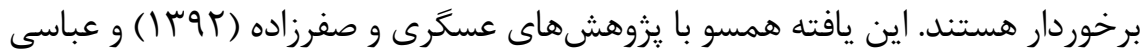


و همكاران (r (1 ) مىباشد. نخرش دينى طبعاً با اثر بر روى مؤلفههاى مختلف عملكرد تحصيلى، سبب افزايش آن مى گردد؛ كه از جملهاين مؤلفهها خودكارامدى است. در اين جا شايسته است به بيان استاد مطهرى اشاره شود كه لايمان مذهبى ازآنجهت كه تلقى انســان را نسبت به جهان، شــكل خاص مى خهد؛ آفرينش را هدفدار و هدف را خير و تكامل و سعادت معرفى مى كند، طبعاً ديد انسان را نسبت به نظام كلى هستى و قوانين

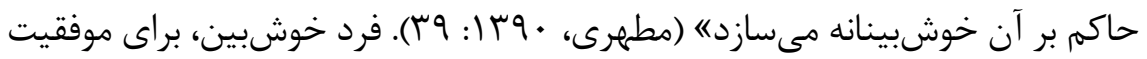

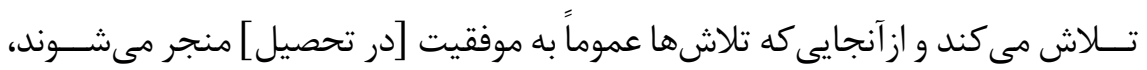
منطقى اسـت كه فرد مذهبى و يرتلاش در اثر موفقيتهـــاى روزافزون، خود كارامدى ميى بهترى را نيز يرورش خواهد داد. برنامهريزى از مؤلفههاى مهلم در عملكرد تحصيلى بهتر

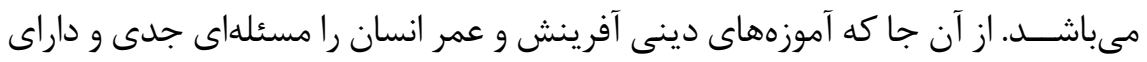
هدف بلند و با اهميت معرفى مى كند، جهره يكى انسان مسلمان و موحد، اساساً جهره يكى إنى انسان جدى است. او زندگى خود را جدى مى گيرد و در تمام عرصههاى زندگى خود، به تبع دين دارى كه بزركترين و مهمترين برنامه براى سعادت او است، بدون اهمال كارى، كمتوجهى و بىدقتى، برنامهريزى و حركت به سوى اهداف را سرلوحه كارهاى خود قرار

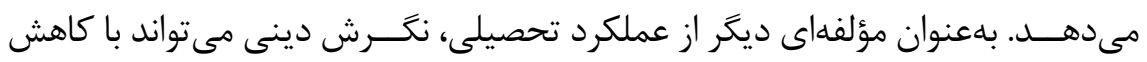
تأثيرات هيجانى (كه هيجانات منفى در طول تحصيل هستند) منجر به عملكرد تحصيلى بهتر شود. افراد با عقايد مذهبى، نسبت به فشار زاهاى روانى، شخصى و عملكرد تحصيلى، از نيروى بيشترى برخوردارند و در رويارويى با آنها كمتر تحت تأثير قرار مى گيرند.

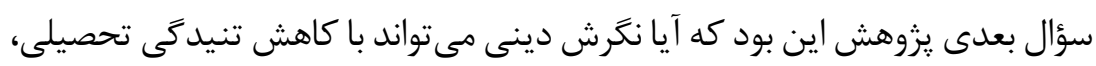

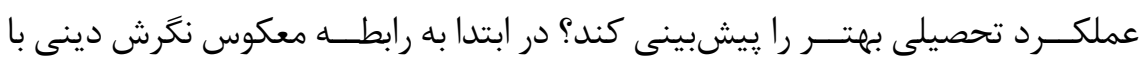
تنيدكى تحصيلى اشـــاره مىشود؛ كه بر اساس يافته يزوهش، نخرش دينى باعث كاهش تنيد

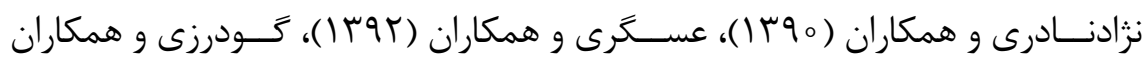

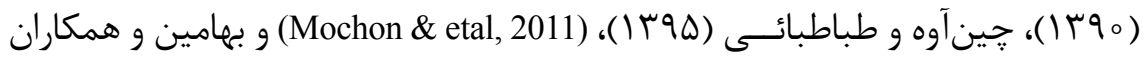
(هو ( ) مىباشد. در تبيين اين يافته، به بيان استاد مطهرى اشاره مى كنيهم كه لاضطراب

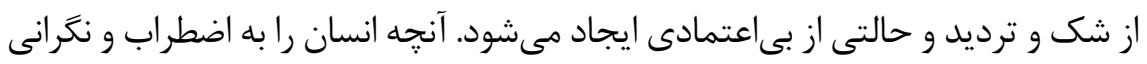
مى كشــاند و تكليف خويش را درباره آن روشن نمىبيند، جهان و محيط بيرونى است. 
ايمان مذهبى از آنجا كه نســـبت به جهان اعتماد و اطمينان مىبخشـــ، دلهره و نغـرانى نســبت به رفتار جهان را در برابر انسان زايل مىسازد و آرامش خاطر به همراه مىآورده

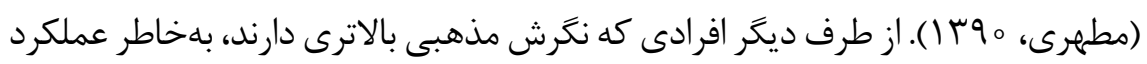
تحصيلى بهتر، تنيدگى و اســترس كمترى را احساس خواهند كرد و اخر هم دجار تنش و فشار شوند، واكنشهاى منفى كمترى بروز خواهند داد. اعتقادات، عواطف و رفتارهاى برخاسته از دين مانند مناجات با خدا و دلبستخى به منبع لايزال قدرت الهى، توان انسان مؤمن را افزايش داده و براى مقابله با فشــارها مسلح مىنمايد. باورهاى دينى به اصلاح

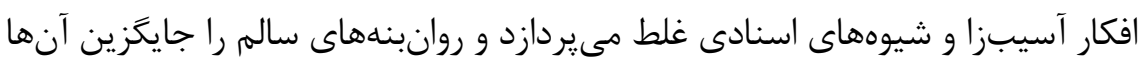
مى كند و در مواجهه با تنشخرها، تكيه به خداوند متعال، عواطف دينى و رفتارهاى آئينى، قوت و نيرو به ارمغان مىآورد. آنها بروز فشار روان را به منزله فرصتى براى رشد و تقويت بعد معنوى خود مى دانند يا آن را تقدير الهى تعبير و تفسير مى كنند. هر ته فرد داراى نكرش مثبت فعال ترى باشـــ، خود كار آمدتر، خودباور انهتر و ســـازشيافتهتر مى تواند در زمانهاى سخت در برابر مشكلات مقابله كند. بنابراين واكنش هاى نامناسب به فشارهاى روانى مانند يرخاشخرى، استرس، افسردگى، اسنادهاى اشتباه، مصرف مواد، خود كشى و... در افراد مذهبى كمتر به جشهم مى خورد.

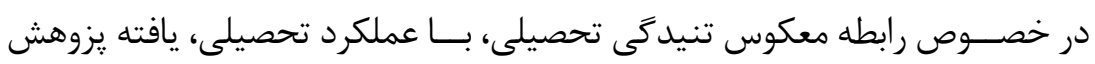
اين رابطه را مورد تأييد قرار داد. اين يافته همســـو با يزوهشهاى آســايش و همكاران

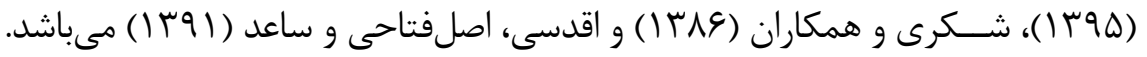
هرجّدر دانشجويان در طول دوره تحصيل، احساس استرس و فشار بيشترى از ناكامىها، تغييرات، تعارضات و تنشخرهاى تحصيلى داشته باشند و واكنشهاى منفى بيشترى به اين فشارها از خود نشان دهند، رفتارهاى درست تحصيلىشان با جالش بيشترى مواجه شـــده و دجار افت عملكرد خواهند شــــ. بنابراين نخرش دينى از طريق كاهش تنيدكى تحصيلى؛ يعنى كاهش فشارها و واكنشهاى منفى و غير انطباقى به آنها، مى تواند سبب

$$
\text { بهبود عملكرد تحصيلى دانشجويان زردد. }
$$

ييشنهادهاى يزوهش:با لحاظ يافتههاى بلدستآ مده بين مؤلفهها، به مسئولين آموزش عالى ييشنهاد مى گردد جهت بهبود عملكرد تحصيلى و كاهش تنيدگى ها، اهتمام جدى در نشر معارف الهى و تقويت ايمان مذهبى داشته باشند. اثرات مثبت ديندارى بر زندكى 
فردى و اجتماعى در مجموعههاى آموزشى و اجتماعات دانشجويان، مورد بحث و بررسى قرار گيرد، تا دانشجويان با آكاهى بيشتر، گرايش بالاترى نسبت به دين و آموزههاى آن پيدا كنند.همجنين مسئولين مجموعههاى آموزشى خود بايد بهعنوان الگوهاى موفقى باشند كه دانشجويان افزايش عملكرد و كاهش تنيدگى ها در عرصههاى مختلف زندگى را در آنها بهعنوان دينداران واقعى مشاهده كنند. اخر در اين جهت تلاش صورت گيرد، فضاى روشن يك زندگى با اعتقادات دينى، دلبستخى ها و عواطف ياك به خداود سبحان و اولياى الهى در دل آنها روشن مىشود و با التزام عملى بهدستورات خداود متعال كه بر اساس لطف الهى است، علاوه بر افزايش توان و انگيزه انسان، او را از تنشها و اضطرابهاى توان فرسا جدا مى كند. بنابر اين كاهش تنيدكى تحصيلى و افزايش مستقيمى و غيرمستقيم عملكرد تحصيلى از نتايج اين تلاشها خواهد بود. البته با لحاظ روابط نسبتاً ضعيف بين مؤلفههاى سهَانه بيان شــده، براى اطمينان از وجود و قدرت اين رابطه، لازم است كه تحقيقات در جوامع ديگر و با ابزارهاى تكميلى از جمله ابزار مصاحبه و يا مشاهده انجام يذيرد، يافتههاى اين تحقيقات مىتواند يافتههاى تحقيق كنونى را تكميل و اصلاح كند.

\section{تشكّر و قدردانى:}

از معاونت محترم يزوهشى دانشكده ادبيات و علوم انسانى دانشگاه قم بهخاطر فراهم

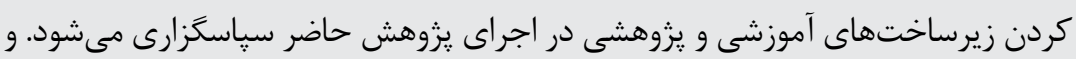

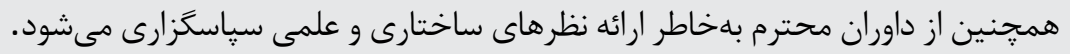




\section{منابع}

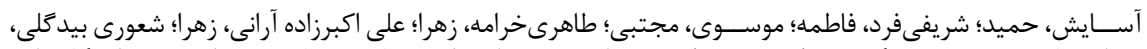

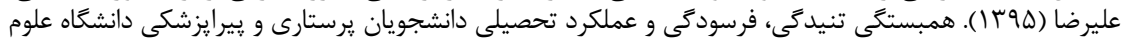

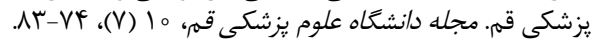

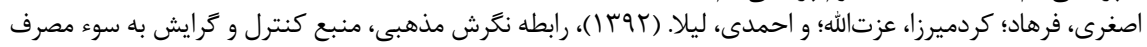

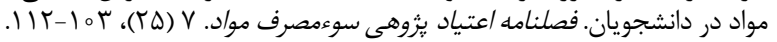

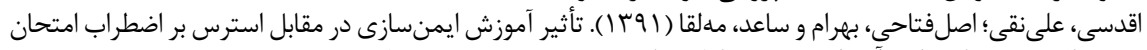

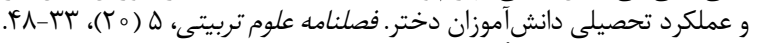

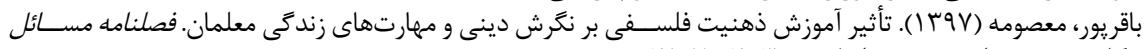

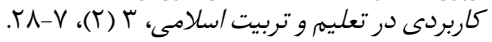

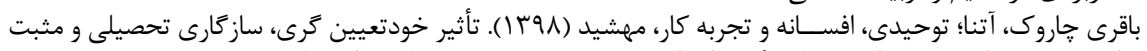

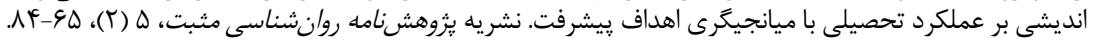
[10.22108/PPLS.2019.117257.1748]

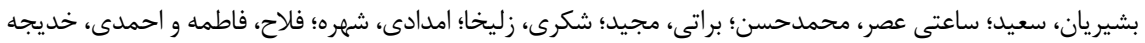

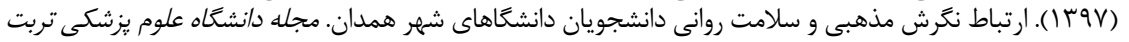

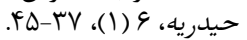

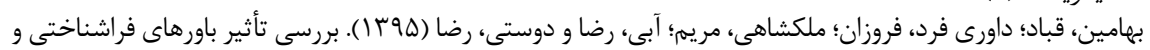

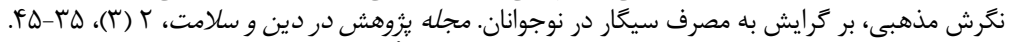

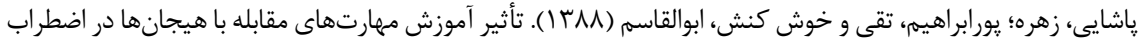

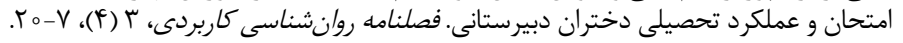

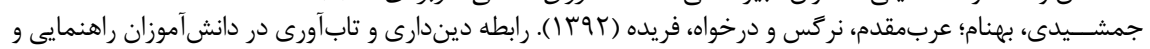

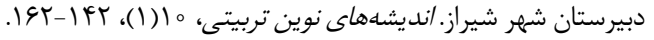

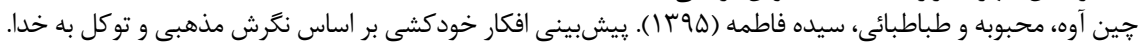

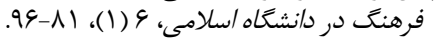

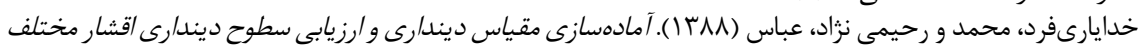

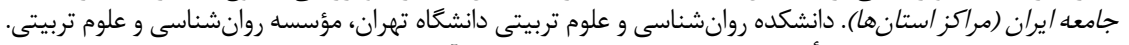

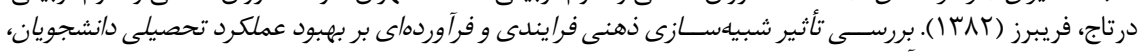

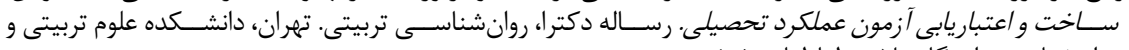

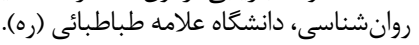

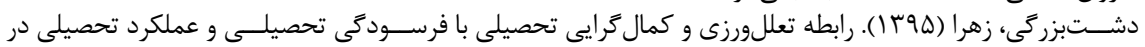

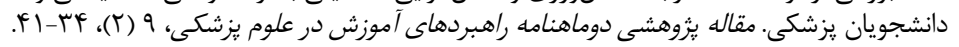

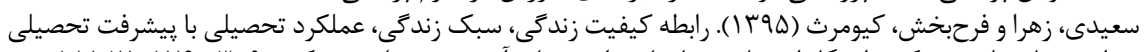

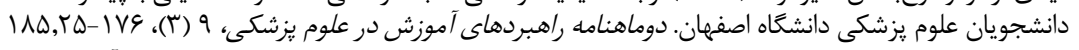

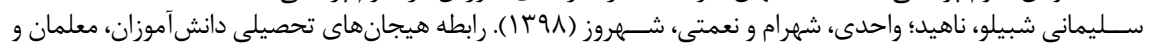

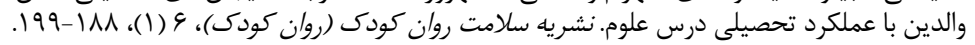

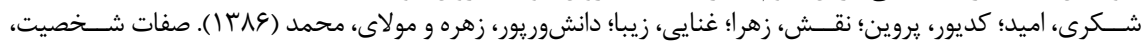

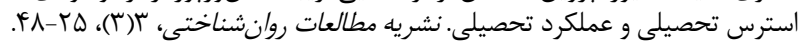

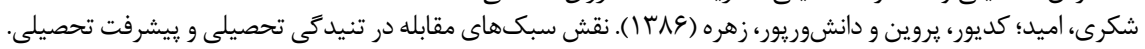

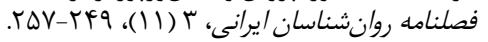

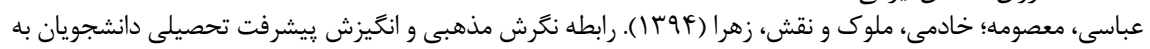

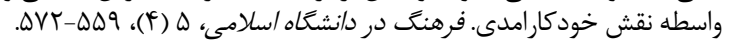

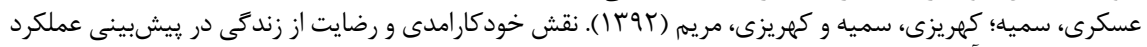

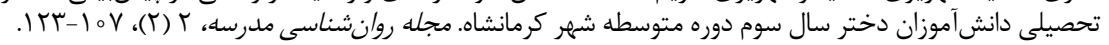

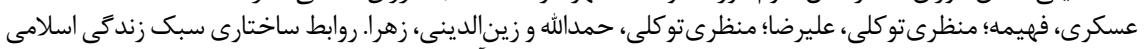

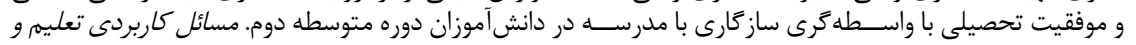

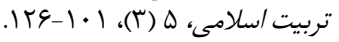

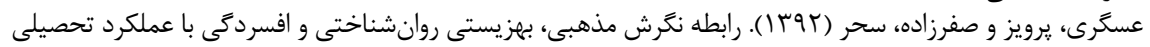

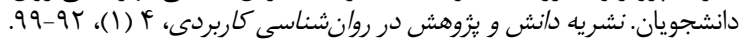

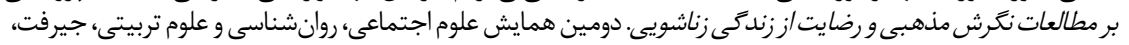
https://civilica.com/doc/786672/ 


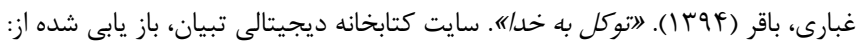
http//:library.tebyan.net/fa/Viewer/Text74094/1/

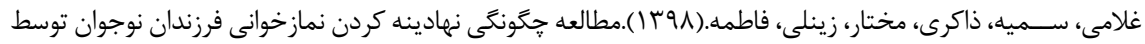

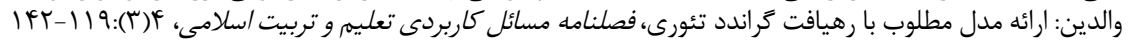

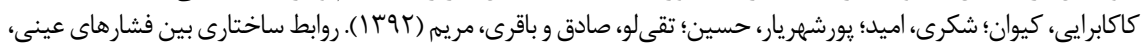

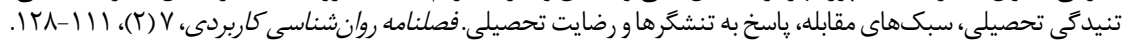

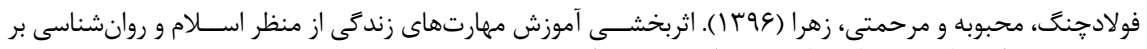

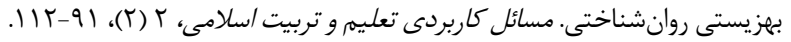

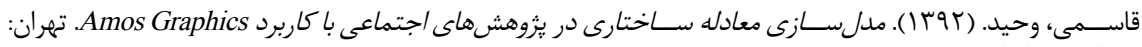

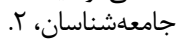
كودرزى، محمدعلى؛ شــــيعى، فائزه و تاريخى، عليرضا (

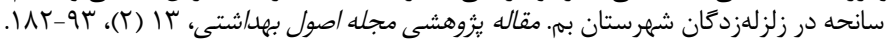

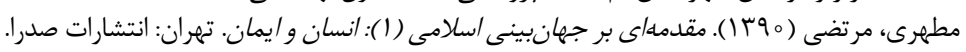

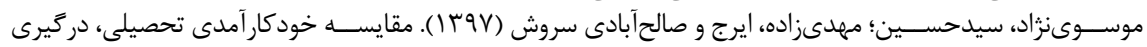

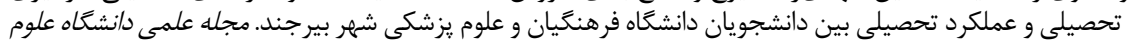

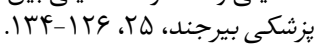

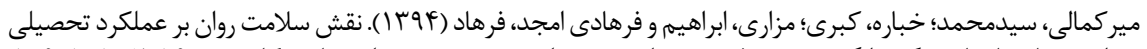

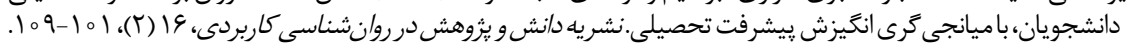

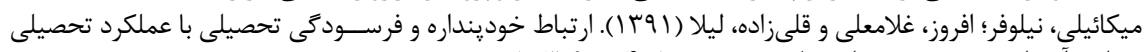

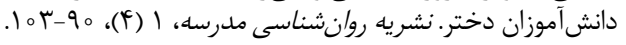

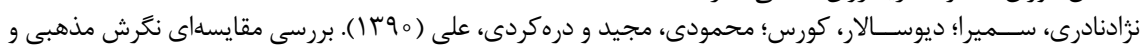

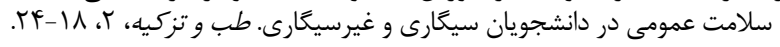

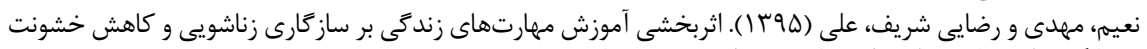

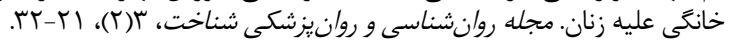

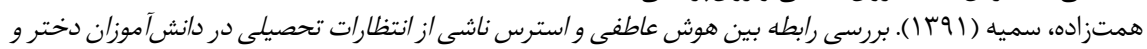

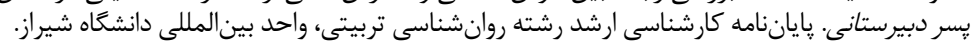

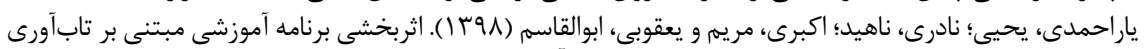

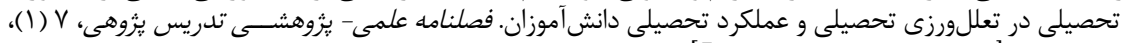

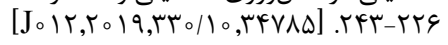

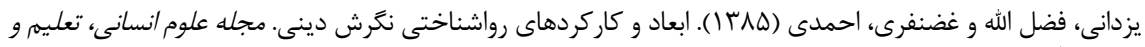

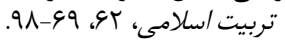

\section{REFERENCES}

Deb, S. Strodl, E. \& Sun, J. (2015). Academic stress, parental pressure, anxiety and mental health among Indian high school students. International Journal of Psychology and Behavioral Sciences, $5(1), 26-34$.

Gadzella,B.M. Baloglu,M. (2001). Confirmatory Factor Aactor Analysis and Internal Consistency of Student Life Stess Inventory.

Kariv, D. \& Heiman, T. (2005). Stressors, stress and coping in dual-demand environments: The case of working 'back to schoolers'. Journal of Adult and Continuing Educatio, 11 (10), 91-110.

Mochon, D.; M.I. Norton \& D. Ariely (2011). «Who Benefits from Religion?». Social Indicators Research, 101 (1), 1-15.

Salehi I, Mosalman M (2015). Evaluation of the relationship between religious attitude and depression, anxiety and stress in students of guilan university. Religion \& Health, 3 (1), 57-64. (Full Text in Persian).

Seif, A. (2016). Modern Psychology: Psychology of Learning and Education. Tehran: Publishing duran. [In Persian]

Trevino, Kelly M. Pargament, Kenneth I. Cotton, Sian. Leonard, Anthony C. Hahn, June. CapriniFaigin, Carol Ann. Tsevat, Joel. (2007). Religious coping and physiological, psychological, social, and spiritual outcomes in patients with HIV/AIDS: Cross-sectional and longitudinal findings, AIDS and Behavior (online).

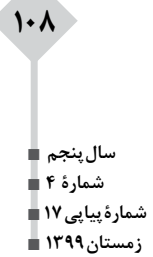

